\title{
Anti-Proliferative Effects of Two New Lactobacillus Strains of Human Origin on Caco-2 Cell Line
}

\author{
Simin Arian ${ }^{1}$, Hami Kaboosi ${ }^{1,{ }^{*},}$, Zaheir Heshmatipour ${ }^{2}$, Zeinab Khazaei Koohpar ${ }^{3}$ and Fatemeh \\ Pyravii-Ghadikolaii ${ }^{4}$ \\ ${ }^{1}$ Department of Microbiology, Ayatollah Amoli Branch, Islamic Azad University, Amol, Iran \\ ${ }^{2}$ Department of Microbiology, Faculty of Biological Sciences, Tonekabon Branch, Islamic Azad University, Tonekabon, Iran \\ ${ }^{3}$ Department of Cellular and Molecular Biology, Faculty of Biological Sciences, Tonekabon Branch, Islamic Azad University, Tonekabon, Iran \\ ${ }^{4}$ Department of Microbiology, Ghaemshahr Branch, Islamic Azad University, Ghaemshahr, Iran \\ "Corresponding author: Department of Microbiology, Ayatollah Amoli Branch, Islamic Azad University, Amol, Iran. Email: hkaboosi@gmail.com
}

Received 2018 September 27; Revised 2019 March 03; Accepted 2019 March 05.

\begin{abstract}
Background: Anti-proliferative effects of probiotics are considerable in the treatment of various cancers, including colon cancer. In the present study, two new Lactobacillus strains as probiotics were isolated from stool samples at a clinical lab.

Objectives: The aim of this study was to evaluate the effects of the cell-free lyophilized filtrate of two new strains of Lactobacillus, isolated on viability on Caco-2 cells.

Methods: Two new strains of Lactobacillus were isolated from $1 \mathrm{gr}$ of each infant stool specimens from a total of fifty volunteers, according to the principles of a scientific questionnaire. The anti-proliferative effects of the strains were investigated using the MTT assay with Caco-2 cell lines.

Results: Out of 50 samples, seven isolates were lactic acid bacteria, two strains of which were probiotics related to L.fermentum (E) and $L$. rhamnosus $(G)$. The results showed that the two Lactobacillus strains had good anti-proliferative effects against the cancer cell lines tested. These strains were resistant to low $\mathrm{pH}$ and $0.3 \%$ bile salt. Cytotoxicity assay revealed that the most effective concentration of strains $\mathrm{E}(\sim 55 \%$ to $\sim 72 \%)$ and G ( $\sim 60 \%$ to $\sim 80 \%)$ on Caco-2 cells was $10000 \mu \mathrm{g} / \mathrm{mL}$ after 24 to 72 hours.

Conclusions: Cytotoxicity effect of the cell-free lyophilized filtrate of bacteria on Caco-2 cells in a dose-and time-dependent manner suggested that these strains might be used in colon cancer therapy.
\end{abstract}

Keywords: Bacteria, Caco-2 Cells, Cancer, Cell Line, Colon, Lactic Acid, Lactobacillales, L. fermentum, L. rhamnosus, MTT Assay

\section{Background}

Probiotics are known as live microorganisms (bacteria or yeasts) and when administered in sufficient numbers, confer a health benefit on the host $(1,2)$. The colonic microflora is dominated by anaerobic bacteria, such as Lactobacillus spp., Bacteroides spp., Fusobacterium spp., and many others. Consumption of probiotics in humans has shown that they are effective in medical problems, such as lactose intolerance, antibiotic-induced diarrhea, gastroenteritis, constipation, and genitourinary tract infections (3). Different studies have shown the anti-proliferative and anti-cancerous properties of probiotics (4). Anti-cancer effects of probiotic bacteria are mediated by inhibition of carcinogens products (5), DNA protection from oxidation, immune system regulation (6), and deregulation of genes implicated in apoptosis, invasion, metastasis, stem cell maintenance, and cell cycle control (5). Furthermore, it ap- pears that probiotic therapy is an effective strategy to improve and overcome gastrointestinal cancers and inflammations. The aim of this study was to evaluate the antiproliferative efficacy of two isolated strains of L. fermentum (E) and L. rhamnosus (G) from healthy volunteers' stools in Tonekabon city (west of Mazandaran province, Iran) that were cultured on colorectal cancer cell lines (Caco-2). Colorectal Cancer (CRC) is one of the important causes of morbidity and mortality, worldwide, through cancer (7). Genetic background and environmental factors, such as lifestyle and diet, play critical roles (8). The intestinal microbiota is composed of bacteria, viruses, archaea, and fungal species (9), which is essential to protect the local homeostasis and epithelial defense against pathogens (10). Probiotics can regulate unbalanced intestinal microbiota, and by decreasing carcinogenic-stimulating occurrence in the colorectal area, can be used as a therapeutic and preventive strategy (8). 


\section{Objectives}

Novel strains with more functional probiotic properties than the existing ones are the object of new research due to the growing demand for "healthy" foods in the food industry. In the present study, two isolated and identified Lactobacillus strains, which were first isolated from human stools, were used to investigate their anti-cancer activity.

\section{Methods}

\subsection{Sampling and Isolation of Bacteria}

The isolated samples were human stool samples obtained from 50 healthy children, according to the principles of a scientific questionnaire at Tonekabon Hospital of Mazandaran province of Iran. Infants were selected at the age of two months to two years, and those with digestive problems were excluded. Once samples were delivered to the laboratory, they were taken to the procedure for isolation and were stored at $4^{\circ} \mathrm{C}$. The isolates were grown on MRS agar (de Man, Rogosa, and Sharpe medium; Quelab, Canada) and incubated at $37^{\circ} \mathrm{C}$ for 24,48 , and 72 hours under anaerobic conditions. All isolates were sub-cultured at least three times before being used. Standard diagnostic and biochemical tests were used to isolate probiotic strains, such as carbohydrate fermentations, acid tolerance assay, and tolerance against bile $(4,11)$.

\subsection{Carbohydrate Fermentations}

Positive isolates were characterized according to their fermentation profiles of ability to ferment 15 different carbohydrates. Overall, $2 \%$ final sugar concentration was obtained. After overnight incubation at $37^{\circ} \mathrm{C}$, the turbidity and the color changed from purple to yellow, which was recorded as positive fermentation results. Also, positive and negative controls were used to indicate any contamination (Table 1) (12).

\subsection{Tolerance to Acidic $p H$ Values}

After isolation of seven lactobacilli, to define gastric acidic tolerance conditions, isolates were grown in MRS broth at $37^{\circ} \mathrm{C}$ for 18 hours. Then, $0.1 \mathrm{~mL}$ aliquots of each active culture was adjusted to $\mathrm{pH} 2.5$ with $5 \mathrm{M} \mathrm{HCl}$ and cultured in MRS agar and incubated at $37^{\circ} \mathrm{C}$ under anaerobic conditions for 24 to 48 hours. All the experiments were replicated twice (13).

\begin{tabular}{lcc}
\hline Table 1. Biochemical Test Results of Isolates & & \\
\hline Tests & \multicolumn{3}{c}{ Strain Code } & \\
\cline { 2 - 3 } & SG & SE \\
\hline Gram test & + & + \\
\hline Bile salt tolerance & $<2 \mathrm{~h}$ & $24 \mathrm{~h}$ \\
\hline pH tolerance & ++ & +++ \\
\hline Arabinose & + & + \\
\hline Inositole & - & - \\
\hline Trehalose & + & + \\
\hline Raffinose & - & + \\
\hline Rhamnose & - & - \\
\hline Monitol & + & + \\
\hline Ribose & + & + \\
\hline Xylose & + & + \\
\hline Sucrose & + & + \\
\hline Cellobiose & + & + \\
\hline Fructose & + & + \\
\hline Galactose & + & + \\
\hline Glucose & + & + \\
\hline Lactose & + & + \\
\hline Mannose & + & + \\
\hline S & + & + \\
\hline
\end{tabular}

a ++, Good; +++, Excellent.

\subsection{Bile Tolerance}

The isolates were cultured in MRS broth at $37^{\circ} \mathrm{C}$ overnight; saturated bile solution was prepared separately by dissolving the powdered bile extract (Oxoid). Bile solution was added to two of the cultures to achieve a final concentration of $0.3 \%$ and the second culture with $0 \%$ bile served as the control sample. The cultures were incubated at $37^{\circ} \mathrm{C}$ for 30 minutes, two, four, and 24 hours. The MRS medium containing $0.3 \%$ bile was inoculated with active cultures (incubated for 16 to 18 hours). During the incubation for four hours, viable colonies were enumerated for every hour with pour plate technique and also bacterial growth was monitored by measuring absorbance with a spectrophotometer (Analytik Jena, Germany) at $600 \mathrm{~nm}$. All the experiments were replicated twice (11).

\subsection{Lactobacillus Identification by Molecular Analysis}

Genomic DNA was an extract from isolated lactic acid bacteria by the High Pure PCR Template Preparation Kit (Roche Molecular Systems, Switzerland). Amplification of the 16S rDNA gene was carried out by the master mix kit (Amplification, Denmark ) and in ABI2720 Thermal Cycler (Thermo Fisher Scientific, USA), according to the following program: An initial denaturation at $95^{\circ} \mathrm{C}$ for five 
minutes, 35 cycles at $95^{\circ} \mathrm{C}$ for one minute, $60^{\circ} \mathrm{C}$ for one minute, $72^{\circ} \mathrm{C}$ for 75 seconds, and a final extension step at $72^{\circ} \mathrm{C}$ for 10 minutes. After the purification of PCR products from agarose gel, DNA sequencing was performed by Macrogen Inc. (Korea). Bacteria-specific primer pairs were 27F (5'-AGAGTTTGATCMTGGCTCAG-3') and 1492R (5'TACGGYTACCTTGTTACGACTT-3') (14). The sequencing results were blasted with the deposited sequences in the National Center for Biotechnology Information (NCBI) and GenBank site (http://blast.ncbi.nlm.nih.gov/Blast.cgi) to identify the isolated bacteria cells. Based on the sequencing results, a phylogenic tree was drawn for probiotic strains (Figure 1).

\subsection{Cell Viability Test (MTT Assay)}

The MTT assay (3- (4, 5-dimethylthiazol-2-yl) 2, 5diphenyl tetrazolium bromide) is an essential test to determine the percentage of cell viability. Briefly, $15 \times 10^{3}$ Caco2 cells/well were seeded in 0.2-mL 96-well flat-bottomed tissue culture-untreated plates and cultured for 24 hours. The culture medium was removed and different concentrations $(0,0.1,1,10,100,1000$, and $10000 \mu \mathrm{g} / \mathrm{mL})$ of cellfree lyophilized filtrate (for L. fermentum and L. rhamnosus separately) were added to the culture medium for eight, $12,24,48$ and 72 hours at $37^{\circ} \mathrm{C}$. Then, MTT dye $(0.5 \mathrm{mg} / \mathrm{mL}$; Sigma Aldrich) was added to each well and incubated at $37^{\circ} \mathrm{C}$ for two hours. To dissolve the formazan crystals, 100 $\mu \mathrm{L}$ of Dimethyl-Sulfoxide (DMSO) was added. The optical density was measured at $570 \mathrm{~nm}$ using an Enzyme-Linked Immunosorbent Assay (ELISA) microplate reader. Each experiment was performed a minimum of three times (15).

\subsection{Statistical Analysis}

One-way Analysis of Variance (ANOVA) with post-hoc Tukey and Kruskal-Wallis tests were used to compare the differences between bacteria strains. The results are presented as mean \pm SD.

\section{Results}

\subsection{Chemical Molecular Identification of the Isolates}

Out of 50 isolates, seven isolates were gram-positive, catalase negative, and rods shape. These isolates gave positive results with the carbohydrates, such as glucose, xylose, ribose, arabinose, mannose, raffinose, galactose, fructose, sucrose, fructose, and lactose. The microbial isolates were taxonomically characterized by 165 rDNA sequence analysis. The analysis of the $16 \mathrm{~S}$ rDNA sequence of strain $\mathrm{E}$ indicated that this new strain is closely related (86\%) to Lactobacillus fermentum. Also, strain $\mathrm{G}$ was determined as a new strain that is closely related (61\%) to Lactobacillus rhamnosus, which is observed in the phylogenetic tree pattern, as shown in the Figure 1. Other lactic acid bacteria strains, including strains $\mathrm{K}, \mathrm{O}, \mathrm{N} 3$, and $\mathrm{N} 5$ were identified as closely related strains to Lactobacillus fermentum, Enterococcus faecium, Enterococcus durans, and Enterococcus faecium, respectively.

\subsection{Tolerance to Acid of Lactobacilli}

According to this experiment, $\mathrm{G}$ and $\mathrm{E}$ isolates were resistant to low $\mathrm{pH}$. Bacteria growth at different $\mathrm{pH}$ values was measured in three grades (weak $=1$, good $=2$, and perfect $=3$ ). Strain G had good growth at $\mathrm{pH} 2.5$ and $\mathrm{pH}$ 3.0, while at $\mathrm{pH} 3.5$ to 5.0, revealed perfect growth for this strain. Strain E had perfect growth at all low $\mathrm{pH}$ values. Thus, strain E was more tolerated to low $\mathrm{pH}(<3.0)$ than strain G. According to the current results based on Kruskal Wallis test, there was no significant difference to resistance level between isolates ( $\mathrm{P}>0.05)$, as shown in Table 2 .

\subsection{Bile Salt Tolerance Assay}

The strains, resistant to low $\mathrm{pH}$, were evaluated for tolerance to the bile salt. All seven lactic acid bacteria isolates were able to grow in $0.3 \%$ bile salt $(\mathrm{P}<0.05)$. Best growth ability (OD $=0.163 \pm 0.004)$ of strain $G$ was exhibited after two hours in $0.3 \%$ bile $(\mathrm{P}<0.05)$. However, strain $\mathrm{E}$ was most tolerated to $0.3 \%$ bile (OD $=0.249 \pm 0.003$ ) after 24 hours $(\mathrm{P}<0.05)$ compared to other time points. The results showed that strain E was further tolerated to $0.3 \%$ bile than strain $\mathrm{G}$ as shown in the Table 3.

4.4. Cytotoxic Effects of Lactobacillus fermentum and Lactobacillus rhamnosus on Caco-2 cells

Inhibition of Caco-2 cell proliferation by the cell-free lyophilized filtrate from L.fermentum (strain E) and L. rhamnosus (strain G) is shown in Tables 4 - 9 respectively, based on different concentrations and times. At concentrations of $0.1 \mu \mathrm{g} / \mathrm{mL}, 1 \mu \mathrm{g} / \mathrm{mL}, 10 \mu \mathrm{g} / \mathrm{mL}$, and $100 \mu \mathrm{g} / \mathrm{mL}$ of strain $\mathrm{G}$ cell-free lyophilized filtrate, a weak inhibition of cell proliferation ( $\sim 20 \%$ to $\sim 30 \%$ ) occurred at 24 and 48 hours of incubation. However, 72 hours after treatment with same concentrations, a few different patterns of cell cytotoxicity were observed ( $\sim 5 \%$ to $\sim 30 \%)$. The cytotoxicity rates were $\sim 40 \%$ for the $1000 \mu \mathrm{g} / \mathrm{mL}$ lyophilized filtrate at 24, 48, and 72 hours of incubation. Nevertheless, 10000 $\mu \mathrm{g} / \mathrm{mL}$ lyophilized filtrate of strain $\mathrm{G}$ was defined as effective concentration of lyophilized filtrate of these bacteria by cytotoxicity amount of $\sim 60 \%$ at 24 hours, $\sim 70 \%$ at 48 hours, and $\sim 80 \%$ at 72 hours. At concentrations of 0.1 $\mu \mathrm{g} / \mathrm{mL}, 1 \mu \mathrm{g} / \mathrm{mL}, 10 \mu \mathrm{g} / \mathrm{mL}$, and $100 \mu \mathrm{g} / \mathrm{mL}$ of strain E cellfree lyophilized filtrate, a weak inhibition of cell proliferation ( $\sim 4 \%$ to $\sim 30 \%$ ) occurred at 24,48 , and 72 hours of 


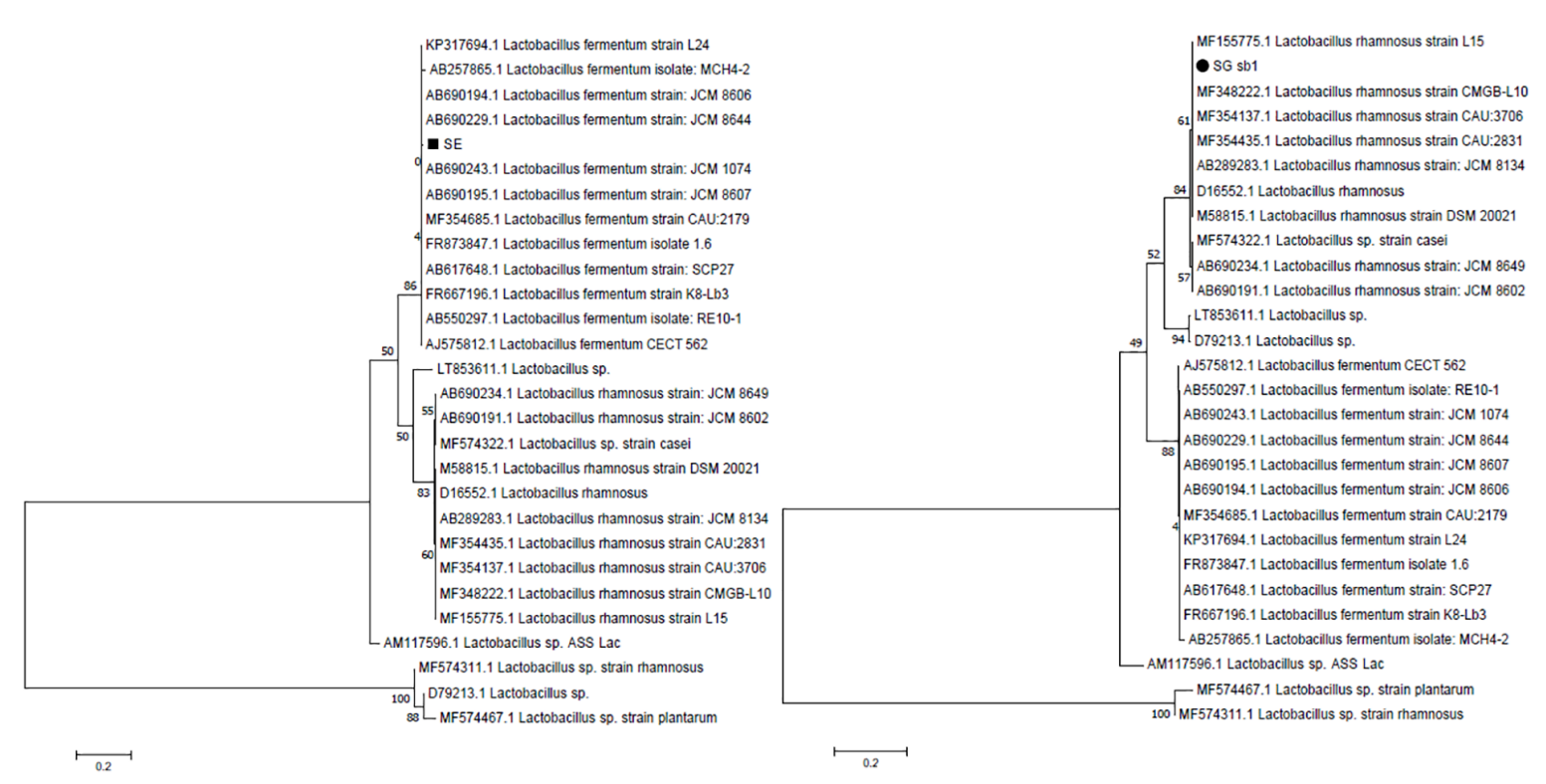

Figure 1. The phylogeny tree plotted for two probiotic s, The G and E strains determined as a new strain as Lactobacillus rhamnosus (61\%) and Lactobacillus fermentum (86\%) respectively.

\begin{tabular}{|c|c|c|c|c|c|c|c|c|}
\hline \multirow{2}{*}{ Strain } & \multicolumn{6}{|c|}{ pH } & \multirow{2}{*}{ Test Statistic } & \multirow{2}{*}{ P Value } \\
\hline & 2.5 & 3 & 3.5 & 4 & 4.5 & 5 & & \\
\hline SG & 2.1 & 2.1 & 3.2 & 3.2 & 3.2 & 3.2 & 3.829 & 0.574 \\
\hline SE & 3.2 & 3.2 & 3.2 & 3.2 & 3.2 & 3.2 & 0.001 & 1 \\
\hline SK & 2.1 & 3.2 & 3.2 & 3.2 & 3.2 & 3.2 & 2.418 & 0.789 \\
\hline SL & 2.1 & 2.2 & 2.1 & 3.2 & 3.2 & 3.2 & 3.992 & 0.551 \\
\hline So & 1.0 & 2.1 & 2.1 & 3.2 & 3.2 & 3.2 & 7.280 & 0.201 \\
\hline $\mathrm{SN}_{3}$ & 1.0 & 2.1 & 2.1 & 3.2 & 3.2 & 3.2 & 7.280 & 0.201 \\
\hline $\mathrm{SN}_{5}$ & 1.1 & 1.1 & 3.2 & 3.2 & 3.2 & 3.2 & 7.014 & 0.220 \\
\hline Strain & $\mathbf{0}$ & $30 \mathrm{~min}$ & $2 \mathbf{h}$ & & $4 \mathrm{~h}$ & $24 \mathrm{~h}$ & Test Statistic & P Value \\
\hline SG & $0.003 \pm 0.055$ & $0.004 \pm 0.093$ & $0.004 \pm 0.163$ & & $0.060 \pm 0.045$ & $0.003 \pm 0.063$ & 9.237 & 0.002 \\
\hline SE & $0.003 \pm 0.086$ & $0.003 \pm 0.076$ & $0.003 \pm 0.082$ & & $0.003 \pm 0.070$ & $0.003 \pm 0.249$ & 2201.983 & 0.001 \\
\hline SK & $0.004 \pm 0.121$ & $0.004 \pm 0.112$ & $0.003 \pm 0.158$ & & $0.003 \pm 0.154$ & $0.003 \pm 0.255$ & 931.365 & 0.001 \\
\hline SL & $0.004 \pm 0.124$ & $0.004 \pm 0.073$ & $0.004 \pm 0.125$ & & $0.397 \pm 0.241$ & $0.035 \pm 1.073$ & 16.756 & 0.001 \\
\hline so & $0.153 \pm 0.233$ & $0.300 \pm 0.400$ & $0.035 \pm 0.847$ & & $0.004 \pm 0.797$ & $0.003 \pm 0.991$ & 13.514 & 0.001 \\
\hline $\mathrm{SN}_{3}$ & $0.003 \pm 0.085$ & $0.003 \pm 0.078$ & $0.003 \pm 0.061$ & & $0.005 \pm 0.487$ & $0.003 \pm 0.444$ & 12140.132 & 0.001 \\
\hline $\mathrm{SN}_{5}$ & $0.004 \pm 0.204$ & $0.003 \pm 0.024$ & $0.004 \pm 0.107$ & & $0.035 \pm 0.153$ & $0.003 \pm 0.992$ & 1830.187 & 0.001 \\
\hline
\end{tabular}

incubation. At concentration of $1000 \mu \mathrm{g} / \mathrm{mL}$, inhibition of Caco- 2 cells viability was $\sim 43 \%$ to $\sim 45 \%$ after one, two, and three days. Effective concentration of strain E cell-free lyophilized filtrate was determined as $10000 \mu \mathrm{g} / \mathrm{mL}$ by cytotoxicity rates of $\sim 55 \%$ to $\sim 72 \%$ after 24 to 72 hours. 


\begin{tabular}{|c|c|c|}
\hline Doses, $\mu \mathrm{g} / \mathbf{m L}$ & Viability & P Value \\
\hline $10000 \mathrm{E}$ & $45.6 \pm 18.41$ & 0.0001 \\
\hline $1000 \mathrm{E}$ & $55.7 \pm 22.51$ & 0.0001 \\
\hline $100 \mathrm{E}$ & $66.8 \pm 27.03$ & 0.0001 \\
\hline $10 \mathrm{E}$ & $77.1 \pm 31.21$ & 0.0001 \\
\hline $\mathbf{1 E}$ & $85.7 \pm 34.67$ & 0.0001 \\
\hline $0.1 \mathrm{E}$ & $90.3 \pm 36.57$ & 0.011 \\
\hline Positive control E & $24.1 \pm 9.70$ & 0.0001 \\
\hline
\end{tabular}

${ }^{\mathrm{a}}$ Values are expressed as mean $\pm \mathrm{SD}$.

Table 5. Anti-Proliferative Effect of Lactobacillus (G Strain) Extracts by MTT Assay (24 h) $)^{\mathrm{a}}$

\begin{tabular}{lcc}
\hline Doses, $\mu$ g/mL & Viability & PValue \\
\hline $\mathbf{1 0 0 0 0}$ E & $39.3 \pm 15.85$ & 0.0001 \\
$\mathbf{1 0 0 0}$ E & $59.3 \pm 23.97$ & 0.0001 \\
\hline $\mathbf{1 0 0}$ E & $70.8 \pm 28.62$ & 0.0001 \\
$\mathbf{1 0}$ E & $74.5 \pm 30.10$ & 0.0001 \\
\hline $\mathbf{1 E}$ & $83.2 \pm 33.64$ & 0.0001 \\
\hline $\mathbf{0 . 1}$ E & $88.1 \pm 35.61$ & 0.0001 \\
\hline Positive control E & $17.7 \pm 7.09$ & 0.0001 \\
\hline
\end{tabular}

${ }^{\text {a }}$ Values are expressed as mean $\pm \mathrm{SD}$.

Table 6. Anti-Proliferative Effect of Lactobacillus (G Strain) Extracts by MTT Assay (48 h) $)^{\mathrm{a}}$

\begin{tabular}{lcc}
\hline Doses, $\mu$ g/mL & Viability & PValue \\
\hline 10000 G & $31.4 \pm 12.68$ & 0.0001 \\
\hline 1000 G & $63.3 \pm 25.59$ & 0.0001 \\
\hline 100 G & $71.6 \pm 28.98$ & 0.0001 \\
\hline 10 G & $76.8 \pm 31.10$ & 0.0001 \\
\hline G & $84.6 \pm 34.26$ & 0.0001 \\
\hline .1G & $89.9 \pm 36.39$ & 0.0001 \\
\hline Positive control G & $13.6 \pm 5.45$ & 0.0001 \\
\hline
\end{tabular}

${ }^{\text {a }}$ Values are expressed as mean $\pm \mathrm{SD}$.

\section{Discussion}

According to past studies, probiotics can inhibit colorectal cancer initiation or progression through change of intestinal microbial compounds, protection against pathogens, production of biological components, such as short-chain fatty acid, inactivation of carcinogenic compounds, regulation of immune responses, apoptosis induction, anti-proliferative activity, and antioxidant properties (16-19). The study of Lee et al. demonstrated that LAB

\begin{tabular}{|c|c|c|}
\hline Doses, $\mu \mathrm{g} / \mathbf{m L}$ & Viability & PValue \\
\hline $10000 \mathrm{E}$ & $37.2 \pm 15.00$ & 0.0001 \\
\hline $1000 \mathrm{E}$ & $56.4 \pm 22.78$ & 0.0001 \\
\hline $100 \mathrm{E}$ & $68.0 \pm 27.51$ & 0.0001 \\
\hline $10 \mathrm{E}$ & $78.6 \pm 31.81$ & 0.0001 \\
\hline $\mathbf{1 E}$ & $86.7 \pm 35.08$ & 0.0001 \\
\hline $0.1 \mathrm{E}$ & $92.0 \pm 37.25$ & .011 \\
\hline Positive control E & $16.9 \pm 6.78$ & 0.0001 \\
\hline
\end{tabular}

${ }^{\text {a }}$ Values are expressed as mean $\pm \mathrm{SD}$.

Table 8. Anti-Proliferative Effect of Lactobacillus (G Strain) Extracts by MTT Assay (72 h) ${ }^{\mathrm{a}}$

\begin{tabular}{lcc}
\hline Doses, $\mu$ g/mL & Viability & P Value \\
\hline 10000 G & $21.9 \pm 8.82$ & 0.0001 \\
1000 G & $64.2 \pm 25.96$ & 0.0001 \\
\hline 100 G & $72.1 \pm 29.18$ & 0.0001 \\
\hline 10 G & $82.4 \pm 33.35$ & 0.0001 \\
\hline G & $87.6 \pm 35.46$ & 0.0001 \\
\hline .1G & $95.3 \pm 38.56$ & 0.002 \\
\hline Positive control G & $12.8 \pm 5.14$ & 0.0001 \\
\hline
\end{tabular}

${ }^{\text {a }}$ Values are expressed as mean \pm SD.

Table 9. Anti-Proliferative Effect of Lactobacillus (E Strain) Extracts by MTT Assay (72

\begin{tabular}{lcc}
\hline Doses, $\mu$ g/mL & Viability & PValue \\
\hline 10000 E & $27.9 \pm 11.26$ & 0.0001 \\
$\mathbf{1 0 0 0}$ E & $57.2 \pm 23.14$ & 0.0001 \\
\hline $\mathbf{1 0 0}$ E & $68.6 \pm 27.76$ & 0.0001 \\
$\mathbf{1 0}$ E & $80.0 \pm 32.39$ & 0.0001 \\
\hline $\mathbf{E}$ & $89.0 \pm 36.03$ & 0.0001 \\
\hline 0.1 E & $96.5 \pm 39.05237$ & 0.048 \\
\hline Positive control E & $13.3 \pm 5.349077$ & $0.0001 \mathrm{~d}$ \\
\hline
\end{tabular}

${ }^{\mathrm{a}}$ Values are expressed as mean $\pm \mathrm{SD}$.

plays an important role in the host immune system to produce anti-tumor effects $(20,21)$. They showed that the butanol extract of B. adolescentis SPM0212 dose-dependently inhibited the growth of Caco-2, HT-29, and SW480 cells by $70 \%, 30 \%$, and $40 \%$, at $200 \mu \mathrm{g} / \mathrm{mL}$, and induced macrophage activation and significantly increased the production of TNF- $\alpha$ and NO, which regulated immune modulation and was cytotoxic to tumor cells (21).

Kumar et al. observed in Caco-2 cells that VK1 inhibited proliferation significantly $(\mathrm{P}<0.05)$ at the highest con- 
centrations (100 and $200 \mu \mathrm{M}$ ). The effect began after 24 hours of infusion and persisted up to 72 hours (by $43.4 \%$ and $44.3 \%$ at 100 and $200 \mu \mathrm{M}$, respectively) (18). All of these prove lactobacillus anti-cancer effects. In this study, the researchers assessed the effect of cell-free lyophilized filtrate from $L$. fermentum and L. rhamnosus on Caco- 2 cells. The results showed that cell-free lyophilized filtrate of these bacteria diminished proliferation and increased Caco 2 cell death in a dose-dependent manner. In Choi et al. study, the inhibitory effect of the soluble polysaccharide derived from Lactobacillus acidophilus 606 was evaluated on the growth of colon cancer cells and hEF cells using MTT. Similar results were found on other cancer cell lines of the present study (22).

Ewaschuk et al. showed that Lactobacillus acidophilus, L. bulgaricus, L. casei, L. plantarum, Bifidobacterium breve, B. infantis, B. longum, and Streptococcus thermophiles decreased the viability of HT-29 and Caco-2 cells and induced cell death (23). Chen et al. found that oral inoculation of probiotics L. acidophilus on CT-26 murine colon adenocarcinoma cells in mice had a cytotoxicity effect and increased apoptosis (24). Gamallat et al. reported that $L$. rhamnosus had a protection effect against colon carcinogenesis and induction of apoptosis in a rat model (25). Gayathri and Asha showed that Lactobacillus fermentum and Lactobacillus plantarum had synergistic effects with vincristine on 1,2-dimethylhydrazine-induced colorectal carcinogenesis in mice (26). In this study, probiotics increased anti-cancerous activity of vincristine. The present study showed that cell-free lyophilized filtrate of L. fermentum and L. rhamnosus had anti-proliferative properties on Caco2 cells.

In a study about anti-cancer effects of probiotics in animal models, Tiptiri-Kourpeti et al. demonstrated that tumor growth inhibited by $10^{9}$ CFU live L. casei for 13 days significantly inhibited in vivo growth of colon carcinoma cells, resulting in approximately $80 \%$ reduction in tumor volume of treated mice. Their findings provided evidence for beneficial tumor-inhibitory, anti-proliferative, and proapoptotic effects driven by this probiotic LAB strain (4). Kahouli and Malhotra reported that L. fermentum NCIMB 5221 significantly inhibited more proliferation of cancer cells than $L$. fermentum NCIMB 2797 after 48 hours $(\sim 46 \%)$ and 72 hours ( $58 \%)$. However, the probiotic treatment was efficient after 72 hours. Also, their study revealed that from three $L$. fermentum strains, only $L$. fermentum NCIMB 5221 had low anti-cancerous activity ( 6\%) after 24 hours (27). In Er et al.'s study $1 \times 106$ Caco-2 cells/well was cultured on a 96-well plate. The effect of L. plantarum was examined by the MTT assay for viability of cultured Caco- 2 cells. They reported that incubation time may influence anti-proliferative activity (28). However in the cur- rent study, the researchers found that L. fermentum (strain E) had high anti-cancerous activity after 24 hours with concentration of $10000 \mu \mathrm{g} / \mathrm{mL}$. Also, other concentrations were more effective than L. fermentum NCIMB 5221 after 24 hours. On the other side, after 48 hours and 72 of the L. fermentum (strain E) at concentration of $10000 \mu \mathrm{g} / \mathrm{mL}$ was more effective than L. fermentum NCIMB 5221. Furthermore, Sadeghi-Aliabadi et al. showed that cell-free filtrate of a commercial strain of L. rhamnosus GG had antiproliferative effect on Caco-2 at 2500 to $10000 \mu \mathrm{g} / \mathrm{mL}$ after 48 hours $(\sim 21 \%$ to $\sim 66 \%$ ) (29). However, in the current study L. rhamnosus (strain G) at concentrations of $1000 \mu \mathrm{g} / \mathrm{mL}$ and $10000 \mu \mathrm{g} / \mathrm{mL}$ had anti-proliferative properties with a rate of $\sim 40 \%$ and $\sim 70 \%$ at 48 hours, respectively. Thus, L. rhamnosus (strain G) was more effective than L. rhamnosus GG. There was a correlation between percentages of anti-proliferation and adhesion to cancer cells from probiotic bacteria (30). Thirabunyanon and Hongwittayakorn showed that ability of the L. fermentum RM28 strain to adhere to Caco-2 cells was 7\%. Anti-proliferative rate of this strain was determined as $\sim 23 \%$ by the MTT assay (30). Verdenelli et al. reported that L. rhamnosus IMC501 had $\sim 15 \%$ adhesion activity to HT-29 colorectal cancer cell line (31). According to these studies, it seems that L. fermentum (strain E) and L. rhamnosus (strain G), through rate of adhesion to Caco-2 cells, can induce anti-proliferative components on these cells. Er et al. investigated the effect of the cell-free lyophilized filtrate of L. plantarum isolated from meat on Caco-2 cell line and observed weak inhibition of Caco-2 cell proliferation ( $\sim 5 \%$ to $14 \%$ ) at concentrations of 0.1 to $1000 \mu \mathrm{g} / \mathrm{mL}$ during 24 hours. The cytotoxicity effect of probiotic extract at concentration of $10000 \mu \mathrm{g} / \mathrm{mL}$ was $33 \%$ at 24 hours of incubation (28). However, extracts of both L. fermentum (strain E) and L. rhamnosus (strain G) in the current study were more effective than L. plantarum in the above-mentioned study at different concentrations after 24 hours. Thus, the use of individual Lactobacillus, such as L.fermentum (strain E) and L. rhamnosus (strain G) or combination of different Lactobacillus strains, to eliminate colorectal cancer cells can be a useful strategy in prevention and treatment. However, further evaluations are required to uncover the usefulness of probiotics in treatment of colorectal cancer in clinical stages. One of the limitations of this study was the lack of time required during the dissertation process, which the researchers hope will continue the project in the future.

\subsection{Conclusions}

In conclusion, both the L. fermentum and L. rhamnosus strains were used in this study, and exhibited 50\% to $80 \%$ killing of the Caco-2 cells. Hence, the two Lactobacillus strains could be considered as common probiotic for 
human consumption, due to their beneficial anticancer effects.

\section{Footnotes}

Authors' Contribution: All the authors had an effective contribution to the manuscript preparation.

Conflict of Interests: The authors declare that they had no competing interests.

Ethics Approval: This study was approved by the Research Ethics Committee of Tonekabon Branch, Islamic Azad University (approved ID: IR.IAU.TON.REC.1397.032) and performed in accordance with the Declaration of Helsinki. The Research Ethics Committee of Tonekabon Branch, Islamic Azad University, approved the study protocol.

Funding/Support: This study was supported by the Islamic Azad University, Ayatollah Amoli Branch, Amol, Mazandaran province, Iran (with registration and grant number 25930597962081). The funding body had no role in the design of the study and collection, analysis, and interpretation of data and in writing the manuscript.

Patient Consent: The participants signed informed consent forms.

\section{References}

1. Zabala A, Martin MR, Haza AI, Fernandez L, Rodriguez JM, Morales P. Anti-proliferative effect of two lactic acid bacteria strains of human origin on the growth of a myeloma cell line. Lett Appl Microbiol. 2001;32(4):287-92. [PubMed: 11298943].

2. Evivie SE, Huo GC, Igene JO, Bian X. Some current applications, limitations and future perspectives of lactic acid bacteria as probiotics. Food Nutr Res. 2017;61(1):1318034. doi: 10.1080/16546628.2017.1318034. [PubMed: 28659729]. [PubMed Central: PMC5475324].

3. Uccello M, Malaguarnera G, Basile F, D’Agata V, Malaguarnera M, Bertino G, et al. Potential role of probiotics on colorectal cancer prevention. BMC Surg. 2012;12 Suppl 1. S35. doi:10.1186/1471-2482-12-S1-S35. [PubMed: 23173670]. [PubMed Central: PMC3499195].

4. Tiptiri-Kourpeti A, Spyridopoulou K, Santarmaki V, Aindelis G, Tompoulidou E, Lamprianidou EE, et al. Lactobacillus casei exerts antiproliferative effects accompanied by apoptotic cell death and upregulation of TRAIL in colon carcinoma cells. PLoS One. 2016;11(2) e0147960. doi: 10.1371/journal.pone.0147960. [PubMed: 26849051] [PubMed Central: PMC4744000].

5. Motevaseli E, Dianatpour A, Ghafouri-Fard S. The role of probiotics in cancer treatment: Emphasis on their in vivo and in vitro anti-metastatic effects. Int J Mol Cell Med. 2017;6(2):66-76. doi 10.22088/acadpub.BUMS.6.2.1. [PubMed: 28890883]. [PubMed Central: PMC5581548].

6. Abedin-Do A, Taherian-Esfahani Z, Ghafouri-Fard S, GhafouriFard S, Motevaseli E. Immunomodulatory effects of Lactobacillus strains: Emphasis on their effects on cancer cells. Immunotherapy. 2015;7(12):1307-29. doi: 10.2217/imt.15.92. [PubMed: 26595390].

7. Thirabunyanon M, Boonprasom P, Niamsup P. Probiotic potential of lactic acid bacteria isolated from fermented dairy milks on antiproliferation of colon cancer cells. Biotechnol Lett. 2009;31(4):571-6. doi: 10.1007/s10529-008-9902-3. [PubMed: 19116692].
8. Kahouli I, Tomaro-Duchesneau C, Prakash S. Probiotics in colorectal cancer (CRC) with emphasis on mechanisms of action and current perspectives. J Med Microbiol. 2013;62(Pt 8):1107-23. doi: 10.1099/jmm.0.048975-0. [PubMed: 23558140].

9. Oke S, Martin A. Insights into the role of the intestinal microbiota in colon cancer. Therap Adv Gastroenterol. 2017;10(5):417-28. doi: $10.1177 / 1756283 X 17694832$. [PubMed: 28507600]. [PubMed Central: PMC5415097].

10. Gao R, Gao Z, Huang L, Qin H. Gut microbiota and colorectal cancer. Eur J Clin Microbiol Infect Dis. 2017;36(5):757-69. doi: 10.1007/s10096016-2881-8. [PubMed: 28063002]. [PubMed Central: PMC5395603].

11. Çakır İ. Determination of some probiotic properties on Lactobacilli and Bifidobacteria [disseration]. Turkey: Ankara University; 2003.

12. Roos S, Engstrand L, Jonsson H. Lactobacillus gastricus sp. nov., Lactobacillus antri sp. nov., Lactobacillus kalixensis sp. nov. and Lactobacillus ultunensis sp. nov., isolated from human stomach mucosa. Int J Syst Evol Microbiol. 2005;55(Pt 1):77-82. doi: 10.1099/ijs.0.63083-0. [PubMed: 15653856].

13. Mojgani N, Hussaini F, Vaseji N. Characterization of indigenous lactobacillus strains for probiotic properties. Jundishapur J Microbiol. 2015;8(2). e17523. doi:10.5812/jjm.17523. [PubMed: 25793099].[PubMed Central: PMC4353062].

14. Fredriksson NJ, Hermansson M, Wilen BM. The choice of PCR primers has great impact on assessments of bacterial community diversity and dynamics in a wastewater treatment plant. PLoS One. 2013;8(10). e76431. doi: 10.1371/journal.pone.0076431. [PubMed: 24098498]. [PubMed Central: PMC3788133].

15. Paolillo R, Romano Carratelli C, Sorrentino S, Mazzola N, Rizzo A. Immunomodulatory effects of Lactobacillus plantarum on human colon cancer cells. Int Immunopharmacol. 2009;9(11):1265-71. doi: 10.1016/j.intimp.2009.07.008. [PubMed:19647100].

16. Subhashini S, Lavanya J, Meignanalakshmi S. In vitro studies on adhesion and the effect of cytotoxicity of bifidobacterium spp. using cell lines. Eur Sci J. 2013;9(18):1857-7881. doi: 10.19044/esj.2013.v9n18p\%25p.

17. de Andrade Calaca PR, Bezerra RP, Albuquerque WWC, Porto ALF, Cavalcanti MTH. Probiotics as a preventive strategy for surgical infection in colorectal cancer patients: A systematic review and metaanalysis of randomized trials. Transl Gastroenterol Hepatol. 2017;2:67. doi: 10.21037/tgh.2017.08.01. [PubMed: 28905008]. [PubMed Central: PMC5590023]

18. Kumar M, Kumar A, Nagpal R, Mohania D, Behare P, Verma V, et al. Cancer-preventing attributes of probiotics: An update. Int J Food Sci Nutr. 2010;61(5):473-96. doi: 10.3109/09637480903455971. [PubMed: 20187714]

19. Orlando A, Linsalata M, Russo F. Antiproliferative effects on colon adenocarcinoma cells induced by co-administration of vitamin K1 and Lactobacillus rhamnosus GG. Int J Oncol. 2016;48(6):2629-38. doi: 10.3892/ijo.2016.3463. [PubMed: 27035094].

20. Schiffrin EJ, Rochat F, Link-Amster H, Aeschlimann JM, DonnetHughes A. Immunomodulation of human blood cells following the ingestion of lactic acid bacteria. J Dairy Sci. 1995;78(3):491-7. doi: 10.3168/jds.S0022-0302(95)76659-0. [PubMed: 7782506].

21. Lee DK, Jang S, Kim MJ, Kim JH, Chung MJ, Kim KJ, et al. Antiproliferative effects of Bifidobacterium adolescentis SPM0212 extract on human colon cancer cell lines. BMC Cancer. 2008;8(1). doi: 10.1186/1471-2407-8-310.

22. Choi SS, Kim Y, Han KS, You S, Oh S, Kim SH. Effects of Lactobacillus strains on cancer cell proliferation and oxidative stress in vitro. Lett Appl Microbiol. 2006;42(5):452-8. doi: 10.1111/j.1472-765X.2006.01913.X. [PubMed: 16620202].

23. Ewaschuk JB, Walker JW, Diaz H, Madsen KL. Bioproduction of conjugated linoleic acid by probiotic bacteria occurs in vitro and in vivo in mice. J Nutr. 2006;136(6):1483-7. doi:10.1093/jn/136.6.1483. [PubMed: 16702308]. 
24. Chen CC, Lin WC, Kong MS, Shi HN, Walker WA, Lin CY, et al. Oral inoculation of probiotics Lactobacillus acidophilus NCFM suppresses tumour growth both in segmental orthotopic colon cancer and extra-intestinal tissue. Br J Nutr. 2012;107(11):1623-34. doi: 10.1017/So007114511004934. [PubMed: 21992995].

25. Gamallat Y, Meyiah A, Kuugbee ED, Hago AM, Chiwala G, Awadasseid A, et al. Lactobacillus rhamnosus induced epithelial cell apoptosis, ameliorates inflammation and prevents colon cancer development in an animal model. Biomed Pharmacother. 2016;83:536-41. doi: 10.1016/j.biopha.2016.07.001. [PubMed: 27447122].

26. Gayathri D; Asha. Synergistic impact of Lactobacillus fermentum, Lactobacillus plantarum and vincristine on 1,2-dimethylhydrazineinduced colorectal carcinogenesis in mice. Exp Ther Med. 2012;3(6):1049-54. doi: 10.3892/etm.2012.536. [PubMed: 22970015]. [PubMed Central: PMC3438560].

27. Kahouli I, Malhotra M. Identification of lactobacillus fermentum strains with potential against colorectal cancer by characterizing short chain fatty acids production, anti-proliferative activity and sur- vival in an intestinal fluid: In vitro analysis. J Bioanalysis Biomed. 2015;7(4). doi: 10.4172/1948-593x.1000132.

28. Er S, Koparal AT, KivanÇ M. Cytotoxic effects of various lactic acid bacteria on Caco-2 cells. TurkJ Biol. 2015;39:23-30. doi: 10.3906/biy-1402-62.

29. Sadeghi-Aliabadi H, Mohammadi F, Fazeli H, Mirlohi M. Effects of Lactobacillus plantarum A7 with probiotic potential on colon cancer and normal cells proliferation in comparison with a commercial strain. Iran J Basic Med Sci. 2014;17(10):815-9. [PubMed: 25729553]. [PubMed Central: PMC4340992].

30. Thirabunyanon M, Hongwittayakorn P. Potential probiotic lactic acid bacteria of human origin induce antiproliferation of colon cancer cells via synergic actions in adhesion to cancer cells and short-chain fatty acid bioproduction. Appl Biochem Biotechnol. 2013;169(2):511-25. doi: 10.1007/s12010-012-9995-y. [PubMed: 23239414].

31. Verdenelli MC, Ghelfi F, Silvi S, Orpianesi C, Cecchini C, Cresci A. Probiotic properties of Lactobacillus rhamnosus and Lactobacillus paracasei isolated from human faeces. Eur J Nutr. 2009;48(6):355-63. doi: 10.1007/s00394-009-0021-2. [PubMed: 19365593]. 